\title{
Role of the gut microbiota in nutrition and health
}

\section{Ana M Valdes and colleagues discuss strategies for modulating the gut microbiota through diet}

and probiotics

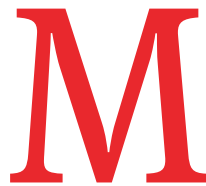

icrobiome refers to the collective genomes of the microorganisms in a particular environment, and microbiota is the community of microorganisms themselves (box 1). Approximately 100 trillion micro-organisms (most of them bacteria, but also viruses, fungi, and protozoa) exist in the human gastrointestinal tract ${ }^{1}$ ${ }^{2}$-the microbiome is now best thought of as a virtual organ of the body. The human genome consists of about 23000 genes, whereas the microbiome encodes over three million genes producing thousands of metabolites, which replace many of the functions of the host, ${ }^{13}$ consequently influencing the host's fitness, phenotype, and health. ${ }^{2}$

\section{Studying the gut microbiota}

Twin studies have shown that, although there is a heritable component to gut microbiota, environmental factors related to diet, drugs, and anthropometric measures are larger determinants of microbiota composition. $^{45}$

Gut microbes are key to many aspects of human health including immune, ${ }^{6}$ metabolic ${ }^{5}$ and neurobehavioural traits (fig 1) ${ }^{78}$ Different levels of evidence support the role of gut microbiota in human health, from animal models ${ }^{910}$ and human studies. ${ }^{411-13}$

Animal models can help identify gut microbes and mechanisms, though the degree to which findings translate to humans is unknown. In humans, observational studies can show crosssectional associations between microbes

\section{KEY MESSAGES}

- Gut microbiota influences many areas of human health from innate immunity to appetite and energy metabolism

- Targeting the gut microbiome, with probiotics or dietary fibre, benefits human health and could potentially reduce obesity

- Drugs, food ingredients, antibiotics, and pesticides could all have adverse effects on the gut microbiota

- Microbiota should be considered a key aspect in nutrition; the medical community should adapt their education and public health messages

- Fibre consumption is associated with beneficial effects in several contexts
Box 1: Glossary

- Microbiome-the collective genomes of the micro-organisms in a particular environment

- Microbiota-the community of micro-organisms themselves

- Microbiota diversity-a measure of how many different species and, dependent on the diversity indices, how evenly distributed they are in the community. Lower diversity is considered a marker of dysbiosis (microbial imbalance) in the gut and has been found in autoimmune diseases and obesity and cardiometabolic conditions, as well as in elderly people

- Operational taxonomic unit-a definition used to classify groups of closely related organisms. DNA sequences can be clustered according to their similarity to one another, and operational taxonomic units are defined based on the similarity threshold (usually $97 \%$ similarity) set by the researcher

- Colonocytes-epithelial cells of the colon

- Germ-free animals-animals that have no micro-organisms living in or on them

- Short chain fatty acids-fatty acids with two to six carbon atoms that are produced by bacterial fermentation of dietary fibres

and health traits but are limited by the inability to measure causal relations. The strongest level of evidence is obtained from interventional clinical studies-in particular, randomised controlled trials.

The composition of gut microbiota is commonly quantified using DNA based methods, such as next generation sequencing of $16 \mathrm{~S}$ ribosomal RNA genes or whole genome shotgun sequencing,

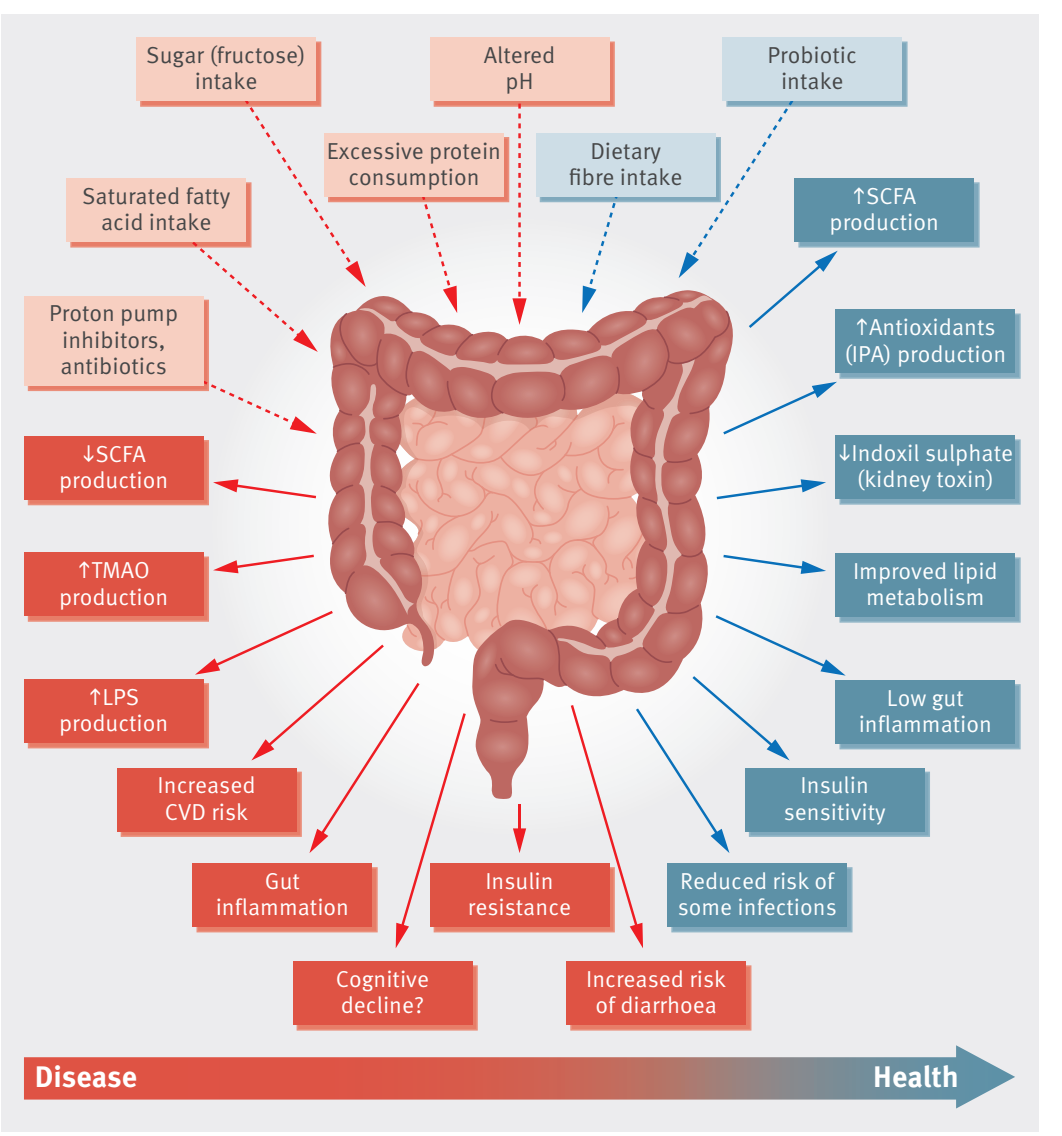

Fig 1 | Schematic representation of the role of the gut microbiota in health and disease giving some examples of inputs and outputs. CVD=cardiovascular disease; IPA=indolepropionic acid; LPS=lipopolysaccharide; SCFA=short chain fatty acids; TMAO=trimethylamine $\mathrm{N}$-oxide 
which also allow inference of microbiota functions. ${ }^{1415}$ Metabolic products of the microbiota are now measurable in stool and serum using metabolomic methods. ${ }^{16}$

\section{What does the gut microbiota do?}

The gut microbiota provides essential capacities for the fermentation of nondigestible substrates like dietary fibres and endogenous intestinal mucus. This fermentation supports the growth of specialist microbes that produce short chain fatty acids (SCFAs) and gases. ${ }^{17}$ The major SCFAs produced are acetate, propionate, and butyrate.

Butyrate is the main energy source for human colonocytes, can induce apoptosis of colon cancer cells, and can activate intestinal gluconeogenesis, having beneficial effects on glucose and energy homeostasis. ${ }^{18}$ Butyrate is essential for epithelial cells to consume large amounts of oxygen through $\beta$ oxidation, generating a state of hypoxia that maintains oxygen balance in the gut, preventing gut microbiota dysbiosis. ${ }^{19}$

Propionate is transferred to the liver, where it regulates gluconeogenesis and satiety signalling through interaction with the gut fatty acid receptors ${ }^{18}$ Acetate-the most abundant SCFA and an essential metabolite for the growth of other bacteria-reaches the peripheral tissues where it is used in cholesterol metabolism and lipogenesis, and may play a role in central appetite regulation. ${ }^{20}$ Randomised controlled trials have shown that higher production of SCFAs correlates with lower diet-induced obesity ${ }^{21}$ and with reduced insulin resistance. ${ }^{22}$ Butyrate and propionate, but not acetate, seem to control gut hormones and reduce appetite and food intake in mice. ${ }^{21}$ Gut microbial enzymes contribute to bile acid metabolism, generating unconjugated and secondary bile acids that act as signalling molecules and metabolic regulators to influence important host pathways. ${ }^{23}$

Other specific products of the gut microbiota have been implicated directly in human health outcomes. Examples include trimethylamine and indolepropionic acid. The production of trimethylamine from dietary phosphatidylcholine and carnitine (from meat and dairy) depends on the gut microbiota and thus its amount in blood varies between people. Trimethylamine is oxidised in the liver to trimethylamine $\mathrm{N}$-oxide, which is positively associated with an increased risk of atherosclerosis and major adverse cardiovascular events. ${ }^{24}$ Indolepropionic acid is highly correlated with dietary fibre intake ${ }^{25}$ and has potent radical scavenging activity in vitro, ${ }^{26}$ which seems to reduce the risk of incidence of type 2 diabetes. ${ }^{25}$

\section{The gut microbiota and obesity}

The gut microbiota seems to play a role in the development and progression of obesity. Most studies of overweight and obese people show a dysbiosis characterised by a lower diversity. ${ }^{31-39}$ Germ-free mice that receive faecal microbes from obese humans gain more weight than mice that receive microbes from healthy weight humans. ${ }^{4}$ A large study of UK twins found that the genus Christensenella was rare in overweight people and when given to germ free mice prevented weight gain. ${ }^{4}$ This microbe and others such as Akkermansia correlate with lower visceral fat deposits. ${ }^{12}$ Although much of the confirmatory evidence comes from mouse models, long term weight gain (over 10 years) in humans correlates with low microbiota diversity, and this association is exacerbated by low dietary fibre intake. ${ }^{28}$

Gut microbiota dysbiosis probably promotes diet induced obesity and metabolic complications by a variety of mechanisms including immune dysregulation, altered energy regulation, altered gut hormone regulation, and proinflammatory mechanisms (such as lipopolysaccharide endotoxins crossing the gut barrier and entering the portal circulation $^{2930}$; fig 1).

\section{Microbiota diversity and health}

Lower bacterial diversity has been reproducibly observed in people with inflammatory bowel disease, ${ }^{31}$ psoriatic arthritis, ${ }^{32}$ type 1 diabetes, ${ }^{33}$ atopic eczema, ${ }^{34}$ coeliac disease, ${ }^{35}$ obesity, ${ }^{36}$ type 2 diabetes, ${ }^{37}$ and arterial stiffness, ${ }^{38}$ than in healthy controls. In Crohn's disease smokers have even lower gut microbiome diversity. ${ }^{39}$ The association between reduced diversity and disease indicates that a species-rich gut ecosystem is more robust against environmental influences, as functionally related microbes in an intact ecosystem can compensate for the function of other missing species. Consequently, diversity seems to be a generally good indicator of a "healthy gut." 4041 But recent interventional studies indicate that major increases in dietary fibre can temporarily reduce diversity, as the microbes that digest fibre become specifically enriched, leading to a change in composition and, through competitive interactions, reduced diversity. ${ }^{22}$

The functional role of the gut microbiome in humans has been shown using faecal microbiota transplantation. ${ }^{42}$ This procedure is effective in cases of severe drug refractory Clostridium difficile infection and is now routinely used for this purpose around the world..$^{43}$ For other pathologies, faecal transplants are not yet clinical practice but have been explored. ${ }^{44}$ For example, transplanting faeces from a lean healthy donor (allogeneic) to recipients with metabolic syndrome resulted in better insulin sensitivity, accompanied by altered microbiota composition, than using autologous faeces. ${ }^{45}$

Effects of food and drugs on the gut microbiota Specific foods and dietary patterns can all influence the abundance of different types of bacteria in the gut, which in turn can affect health (table 1).

High-intensity sweeteners are commonly used as sugar alternatives, being many times sweeter than sugar with minimal calories. Despite being "generally recognised as safe" by regulatory agencies, some animal studies have shown that these sugar substitutes may have negative effects on the gut microbiota. ${ }^{46}$ Sucralose, aspartame, and saccharin have been shown to disrupt the balance and diversity of gut microbiota. ${ }^{46}$ Rats given sucralose for 12 weeks had significantly higher proportions of Bacteroides, Clostridia, and total aerobic bacteria in their guts and a significantly higher faecal $\mathrm{pH}$ than those without sucralose. ${ }^{47}$ Mice given sucralose for six months had an increase in the expression in the gut of bacterial pro-inflammatory genes and disrupted faecal metabolites. ${ }^{48}$

Food additives, such as emulsifiers, which are ubiquitous in processed foods, have also been shown to affect the gut microbiota in animals. ${ }^{49}$ Mice fed relatively low concentrations of two commonly used emulsifiers-carboxymethylcellulose and polysorbate-80-showed reduced microbial diversity compared with mice not fed with emulsifiers. Bacteroidales and Verrucomicrobia were decreased and inflammation promoting Proteobacteria associated with mucus was enriched. ${ }^{49}$

Other areas of concern include the side effects of popular restrictive diets on gut health. These include some strict vegan diets, raw food or "clean eating" diets, gluten-free diets, and low FODMAP (fermentable oligosaccharides, disaccharides, monosaccharides, and polyols) diets used to treat irritable bowel syndrome.

Vegans are viewed by some as healthier than omnivores. A study of 15 vegans and 16 ominvores found striking differences in serum metabolites generated by the gut microbes but very modest differences in gut bacterial communities..$^{50}$ A controlled feeding experiment of 10 human omnivores randomised to receive either a high fat and low fibre diet or a low fat and high fibre for 10 days found very modest effects on gut microbiome composition and no difference in short chain fatty acid production. Together these data support a greater role for diet influencing the bacterial derived metabolome than just the short term bacterial community. ${ }^{50}$ 


\begin{tabular}{|c|c|c|c|c|}
\hline Dietary element & Effect on gut microbiome & $\begin{array}{l}\text { Effect on health outcomes mediated by } \\
\text { gut microbiome }\end{array}$ & $\begin{array}{l}\text { Human observational } \\
\text { studies }\end{array}$ & $\begin{array}{l}\text { Human interventional } \\
\text { studies }\end{array}$ \\
\hline Low FODMAP diet & $\begin{array}{l}\text { Low FODMAP diet increased Actinobacteria; high FODMAP diet } \\
\text { decreased abundance of bacteria involved in gas consumption }{ }^{58}\end{array}$ & $\begin{array}{l}\text { Reduced symptoms of irritable bowel } \\
\text { syndrome }\end{array}$ & Yes & Yes \\
\hline Cheese & $\begin{array}{l}\text { Increased Bifidobacteria, }{ }^{9798} \text { which are known for their positive } \\
\text { health benefits to their host through their metabolic activities. }{ }^{99} \\
\text { Decrease in Bacteroides and Clostridia, some strains of which are } \\
\text { associated with intestinal infections }{ }^{98}\end{array}$ & $\begin{array}{l}\text { Potential protection against } \\
\text { pathogens. }{ }^{100} \text { Increased production of } \\
\text { SCFA and reduced production of TMAO }{ }^{99}\end{array}$ & Yes & Yes \\
\hline Fibre and prebiotics & Increased microbiota diversity and SCFA production 22101102 & $\begin{array}{l}\text { Reduced type } 2 \text { diabetes }^{22} \text { and } \\
\text { cardiovascular disease }^{103}\end{array}$ & Yes & Yes \\
\hline Artificial sweeteners & $\begin{array}{l}\text { Overgrowth of Proteobacteria and Escherichia coli. }{ }^{104} \text { Bacteroides, } \\
\text { Clostridia, and total aerobic bacteria were significantly lower, and } \\
\text { faecal pH was significantly higher }{ }^{47}\end{array}$ & Induced glucose intolerance ${ }^{105}$ & No & No \\
\hline $\begin{array}{l}\text { Polyphenols (eg, from } \\
\text { tea, coffee, berries, } \\
\text { and vegetables such } \\
\text { as artichokes, olives, } \\
\text { and asparagus) }\end{array}$ & $\begin{array}{l}\text { Increased intestinal barrier protectors (Bifidobacteria and } \\
\text { Lactobacillus), butyrate producing bacteria (Faecalibacterium } \\
\text { prausnitzii and Roseburia) and Bacteroides vulgatus and } \\
\text { Akkermansia muciniphila. }{ }^{107} \text { Decreased lipopolysaccharide } \\
\text { producers (E coli and Enterobacter cloacae) })^{106}\end{array}$ & $\begin{array}{l}\text { Gut micro-organisms alter polyphenol } \\
\text { bioavailability resulting in reduction } \\
\text { of metabolic syndrome markers and } \\
\text { cardiovascular risk markers }^{108}\end{array}$ & Yes & Yes \\
\hline Vegan & $\begin{array}{l}\text { Very modest differences in composition and diversity in humans } \\
\text { and strong differences in metabolomic profile compared with } \\
\text { omnivore diet in humans }{ }^{50}\end{array}$ & $\begin{array}{l}\text { Some studies show benefit of vegetarian } \\
\text { over omnivore diet, }{ }^{109} \text { others fail to find a } \\
\text { difference }^{110}\end{array}$ & Yes & Yes \\
\hline
\end{tabular}

Animal and in vitro studies indicate that gluten-free bread reduces the microbiota dysbiosis seen in people with gluten sensitivity or coeliac disease. ${ }^{5152}$ But most people who avoid gluten do not have coeliac disease or proved intolerance, and a recent large observational study showed an increased risk of heart disease in gluten avoiders, potentially because of the reduced consumption of whole grains. ${ }^{53}$ One study showed that 21 healthy people had substantially different gut microbiota profiles after four weeks on a gluten-free diet. Most people showed a lower abundance of several key beneficial microbe species. ${ }^{54}$

The low FODMAP diet has been shown in six randomised controlled trials to reduce symptoms of irritable bowel syndrome. ${ }^{556}$ It is associated with a reduced proportion of Bifidobacterium in patients with irritable bowel syndrome, and responsiveness to this diet can be predicted by faecal bacterial profiles. ${ }^{57}$ Low FODMAP diets lead to profound changes in the microbiota and metabolome, the duration and clinical relevance of which are as yet unknown. ${ }^{5859}$

In addition to diet, medication is a key modulator of the gut microbiota composition. A large Dutch-Belgian population study showed that drugs (including osmotic laxatives, progesterone, TNF- $\square$ inhibitors and rupatadine) had the largest explanatory power on microbiota composition $(10 \%$ of community variation). ${ }^{13}$ Other studies have shown major effects of commonly prescribed proton pump inhibitors on the microbial community, which could explain higher rates of gastrointestinal infection in people taking these drugs. ${ }^{60}$ Antibiotics clearly have an effect on gut microbes, and low doses are routinely given to livestock to increase their growth and weight. A large proportion of antibiotic use in many countries is for agriculture-particularly intensive farming of poultry and beef. ${ }^{61}$ Several observational human studies as well as many rodent studies have pointed to an obesogenic effect of antibiotics in humans even in tiny doses found in food. ${ }^{61}$ But humans have very variable responses to antibiotics, and intervention studies have not shown consistent metabolic consequences. ${ }^{62}$ Pesticides and other chemicals are commonly sprayed on foods, but, although levels can be high, solid evidence for their harm on gut health and the effects of organic food is currently lacking. ${ }^{63}$

Insufficient clinical evidence exists to draw clear conclusions or recommendations for these or other dietary preferences based on gut microbiota. But future studies of food

\section{Box 2: Consensus and uncertainties}

\section{What we know}

- Probiotic supplementation has several beneficial effects on human health

- The microbes in our gut influence and human energy metabolism ${ }^{22-45}$

- Diet and medication have a strong influence on gut microbiota composition

- Microbiota composition influences response to chemotherapy and immunotherapy ${ }^{96}$

- Microbiome composition defines glucose response to foods and can be used to personalise $\operatorname{diet}^{94}$

- Dietary fibre intake influences gut microbiota composition and is related to better health 8687104

\section{What we don't know}

- Are natural probiotics in food better than probiotic supplements? Should we take them preventively?

- Can microbes influence food choices and appetite?

- Do low dose antibiotics in food affect human health?

- What is the effect of pesticides in food on the gut microbiome? Is organic food better for the gut microbiota?

- Should all new drugs and food chemicals be tested on the gut microbiota? 


\section{Manipulating the gut microbiota through diet}

Changes to the gut microbiota can occur within days of changing diet; remarkable differences were found after African Americans and rural Africans switched diets for only two weeks. ${ }^{66}$ Increased abundance of known butyrate producing bacteria in the African Americans consuming a rural African diet caused butyrate production to increase 2.5 times and reduced synthesis of secondary bile acid. ${ }^{66}$ Another study comparing extreme shifts between plant and animal protein based diets showed these changes after only five days. ${ }^{67}$ But healthy microbiota are resilient to temporal changes by dietary interventions, meaning that homeostatic reactions restore the original community composition, as recently shown in the case of bread ${ }^{68}$

\section{Prebiotic foods and dietary fibre}

Most national authorities define dietary fibre as edible carbohydrate polymers with three or more monomeric units that are resistant to the endogenous digestive enzymes and thus are neither hydrolysed nor absorbed in the small intestine. ${ }^{69}$ A subset of dietary fibre sources is fermentable, which means that they serve as growth substrates for microbes in the distal bowel. ${ }^{70}$ Some non-digestible carbohydrates have been referred to as "prebiotics," which are defined as food components or ingredients that are not digestible by the human body but specifically or selectively nourish beneficial colonic micro-organisms (box 3). ${ }^{71}$ The prebiotic concept has been criticised for being poorly defined and unnecessarily narrow, ${ }^{72}$ and some scientists prefer the term "microbiota accessible carbohydrates," ${ }^{11}$ which are essentially equivalent to fermentable dietary fibre in that they become available as growth substrates for gut microbes that possess the necessary enzymatic capacity to use them. ${ }^{70}$

Consuming resistant starches has been shown to enrich specific bacterial groups (Bifidobacterium adolescentis, Ruminococcus bromii, and Eubacterium rectale) in some people. ${ }^{7475}$ The taxa enriched differ depending on the type of resistant starches and other dietary fibres, ${ }^{75}$ indicating that shifts are dependent on the carbohydrate's chemical structure and the microbes' enzymatic capacity to access them. Microbes need also to "adhere" to a substrate and tolerate the conditions generated from fermentation (such as low $\mathrm{pH}) .^{76}$

The effect of microbiota accessible carbohydrates on the gastrointestinal microbiome composition can be substantial, with specific species becoming enriched to constitute more than $30 \%$ of the faecal microbiota. ${ }^{7577}$ Thus, microbiota accessible carbohydrates provide a potential strategy to enhance useful minority members of the microbiome. These changes only last as long as the carbohydrate is consumed, and they are highly individual, which provides a basis for personalised approaches. Many short term feeding trials with purified dietary fibres or even whole plant based diets either have no effect on microbiota diversity or reduce it, ${ }^{22}$ but can still have clinical benefits, potentially through metabolites such as small chain fatty acids. ${ }^{2267}$

Low fibre intake reduces production of small chain fatty acids and shifts the gastrointestinal microbiota metabolism to use less favourable nutrients, ${ }^{78}$ leading to the production of potentially detrimental metabolites. ${ }^{79} 80$ Convincing evidence shows that the low fibre Western diet degrades the colonic mucus barrier, causing microbiota encroachment, which results in pathogen susceptibility ${ }^{81}$ and inflammation, ${ }^{82}$ providing a potential mechanism for the links of Western diet with chronic diseases. Two recent studies showed that the detrimental effects of high fat diets on penetrability of the mucus layer and metabolic functions could be prevented through dietary administration of inulin. ${ }^{83}$ ${ }^{84}$ Overall, these findings, together with the role of butyrate in preventing oxygen induced gut microbiota dysbiosis, ${ }^{19}$ provide a strong rational to enrich dietary fibre consumption to maintain intact mucosal barrier function in the gut. ${ }^{85}$

Considerable observational evidence shows that fibre intake is beneficial for

Box 3: What are prebiotics and probiotics?

Dietary amounts of protein, saturated and unsaturated fats, carbohydrates, and dietary fibre influence the abundance of different types of bacteria in the gut. The microbiota can also be modified by adding live micro-organisms to food or by periods of fasting.

- Probiotics are live bacteria and yeasts that, when administrated in a viable form and in adequate amounts, are beneficial to human health. They are usually added to yoghurts or taken as food supplements.

- Prebiotics are defined as a substrate that is selectively used by host micro-organisms conferring a health benefit. Although all compounds considered prebiotics are microbiota accessible carbohydrates or fermentable dietary fibre, the reverse is not true. The prebiotic concept is an area of current debate ${ }^{70}$

- Synbiotics contain a mixture of prebiotics and probiotics

human health. Two recent meta-analyses found clear links between dietary fibre and health benefits in a wide range of pathologies, ${ }^{8687}$ and a recent intervention study found dietary fibres significantly reduced insulin resistance in patients with type 2 diabetes, with clear links to the shifts in the microbiota and beneficial metabolites (such as butyrate). ${ }^{45}$

\section{Probiotic foods}

Probiotics are live micro-organisms that, when administered in adequate amounts, confer a health benefit on the host) ${ }^{88}$ Probiotics (mostly Bifidobacterium and Lactobacillus species) can be included in a variety of products, including foods, dietary supplements, or drugs.

There are concerns that most microbe supplements are unable to establish themselves in the gut and fail to exert an effect on the resident community. ${ }^{8990}$ But probiotics can affect health independently of the gut microbiota through direct effects on the host; for example, through immune modulation or the production of bioactive compounds. The therapeutic effect of probiotic supplementation has been studied in a broad range of diseases.

We searched the Cochrane library of systematic reviews for "probiotic*", yielding 39 studies, and searched Medline for "systematic review" or "meta-analysis" and "probiotic*", yielding 31 studies. We included information on systematic reviews of randomised controlled trials published in the past five years where the main treatment was probiotics (not dietary supplements in general). Only studies that focused on comparisons of probiotics with a control group, that contained at least some moderate or high quality randomised controlled trials in the estimation of the authors of the systematic review, which resulted in a total of 22 systematic reviews (table 2). The analysis of 313 trials and 46826 participants showed substantial evidence for beneficial effects of probiotic supplementation in preventing diarrhoea, necrotising enterocolitis, acute upper respiratory tract infections, pulmonary exacerbations in children with cystic fibrosis, and eczema in children. Probiotics also seem to improve cardiometabolic parameters and reduced serum concentrationof $\mathrm{C}$ reactive protein in patients with type 2 diabetes. Importantly, the studies were not homogeneous and were not necessarily matched for type or dose of probiotic supplementation nor length of intervention, which limits precise recommendations. Emerging areas of probiotic treatment include using newer microbes and combinations, combining probiotics and prebiotics (synbiotics), ${ }^{91}$ and personalised approaches based on 


\begin{tabular}{|c|c|c|c|c|}
\hline Outcome & Reference & $\begin{array}{l}\text { No of studies/ } \\
\text { participants }\end{array}$ & $\begin{array}{l}\text { Evidence of } \\
\text { benefit? }\end{array}$ & Results/conclusions \\
\hline $\begin{array}{l}\text { Clostridium } \\
\text { difficile associated } \\
\text { diarrhoea in adults } \\
\text { and children }\end{array}$ & Goldenberg et al $(2017)^{111}$ & $39 / 9955$ & Yes & $\begin{array}{l}\text { Moderate quality evidence that probiotics are safe and effective for preventing C difficile } \\
\text { associated diarrhoea. (RR } 0.30,95 \% \mathrm{Cl} 0.21 \text { to } 0.42 \text { ) }\end{array}$ \\
\hline $\begin{array}{l}\text { Necrotising } \\
\text { enterocolitis }\end{array}$ & $\begin{array}{l}\text { Al Faleh et al }(2014)^{112} \\
\text { Rees et al }(2017)^{113}\end{array}$ & $17 / 5338$ & Yes & $\begin{array}{l}\text { Enteral supplementation of probiotics prevents severe necrotising enterocolitis (RR } 0.43,95 \% \mathrm{Cl} \\
0.33 \text { to } 0.56 \text { ) and all cause mortality in preterm infants ( } R R 0.65,95 \% \mathrm{Cl} 0.25 \text { to } 0.81 \text { ) }\end{array}$ \\
\hline $\begin{array}{l}\text { Antibiotic } \\
\text { associated } \\
\text { diarrhoea in children }\end{array}$ & Goldenberg et al $(2015)^{114}$ & $26 / 3898$ & Yes & $\begin{array}{l}\text { Moderate evidence of a fall in the incidence of antibiotic associated diarrhoea in the probiotic } v \\
\text { control group (RR } 0.46,95 \% \mathrm{Cl} 0.35 \text { to } 0.61 ;\left.\right|^{2}=55 \%, 3898 \text { participants) }\end{array}$ \\
\hline $\begin{array}{l}\text { Probiotics for } \\
\text { preventing acute } \\
\text { upper respiratory } \\
\text { tract infections }\end{array}$ & Hao et al $(2015)^{115}$ & $12 / 3720$ & Yes & $\begin{array}{l}\text { Probiotics were better than placebo in reducing the number of participants experiencing } \\
\text { episodes of acute upper respiratory tract infections, the mean duration of an episode, antibiotic } \\
\text { use, and related school absence ( } 12 \text { trials, } 3720 \text { participants including children, adults, and } \\
\text { older people) }\end{array}$ \\
\hline $\begin{array}{l}\text { Urinary tract } \\
\text { infections }\end{array}$ & Schwenger et al $(2015)^{116}$ & $9 / 735$ & No & No significant benefit for probiotics compared with placebo or no treatment \\
\hline $\begin{array}{l}\text { Prevention of } \\
\text { eczema in infants } \\
\text { and children }\end{array}$ & Mansfield et al (2014) & $16 / 2797$ & Yes & $\begin{array}{l}\text { Probiotic supplementation in the first several years of life did have a significant impact on } \\
\text { development of eczema (RR } 0.74,95 \% \mathrm{Cl} 0.67 \text { to } 0.82 \text { ) }\end{array}$ \\
\hline $\begin{array}{l}\text { Prevention of } \\
\text { invasive fungal } \\
\text { infections in preterm } \\
\text { neonates }\end{array}$ & Agrawal et al $(2015)^{119}$ & $19 / 4912$ & Unclear & $\begin{array}{l}\text { Probiotic supplementation reduced the risk of invasive fungal infections (RR } 0.50,95 \% \mathrm{Cl} 0.34 \\
\text { to } 0.73, I^{2}=39 \% \text { ) but there was high heterogeneity between studies. Analysis after excluding } \\
\text { the study with a high baseline incidence ( } 75 \% \text { ) showed that probiotic supplementation had no } \\
\text { significant benefits (RR } 0.89,95 \% \mathrm{Cl} 0.44 \text { to } 1.78 \text { ) }\end{array}$ \\
\hline $\begin{array}{l}\text { Prevention of } \\
\text { nosocomial } \\
\text { infections }\end{array}$ & Manzanares et al $(2015)^{120}$ & $30 / 2972$ & Yes & $\begin{array}{l}\text { Probiotics were associated with a significant reduction in infections (RR } 0.80,95 \% \mathrm{Cl} 0.68 \\
\text { to } 0.95, \mathrm{P}=0.009 ; \mathrm{I}^{2}=36 \%, \mathrm{P}=0.09 \text { ). A significant reduction in the incidence of ventilator } \\
\text { associated pneumonia was found ( } \mathrm{RR} 0.74,95 \% \mathrm{Cl} 0.61 \text { to } 0.90, \mathrm{P}=0.002 ;\left.\right|^{2}=19 \% \text { ) }\end{array}$ \\
\hline $\begin{array}{l}\text { Treatment of } \\
\text { rotavirus diarrhoea } \\
\text { in infants and } \\
\text { children }\end{array}$ & Ahmadi et al $(2015)^{121}$ & $14 / 1149$ & Yes & $\begin{array}{l}\text { Probiotic supplementation resulted in a mean difference of }-0.41(\mathrm{Cl} 95 \%-0.56 \text { to }-0.25 \text {; } \\
\text { P<0.001) in the duration of diarrhoea. Probiotics exert positive effect on reducing the duration of } \\
\text { acute rotavirus diarrhoea compared with control }\end{array}$ \\
\hline $\begin{array}{l}\text { Prevention and } \\
\text { treatment of } \\
\text { Crohn's disease and } \\
\text { ulcerative colitis }\end{array}$ & Saez Lara et al $(2015)^{122}$ & $\begin{array}{l}14 / 821 \\
\text { ulcerative colitis } \\
8 / 374 \text { Crohn's } \\
\text { disease }\end{array}$ & Yes & $\begin{array}{l}\text { The use of probiotics and/or synbiotics has positive effects in the treatment and maintenance } \\
\text { of ulcerative colitis, whereas in Crohn's disease clear effectiveness has only been shown for } \\
\text { synbiotics (no meta- analysis was performed) }\end{array}$ \\
\hline $\begin{array}{l}\text { Pulmonary } \\
\text { exacerbations in } \\
\text { children with cystic } \\
\text { fibrosis }\end{array}$ & Ananathan et al (2016) ${ }^{123}$ & $9 / 275$ & Yes & $\begin{array}{l}\text { Significant reduction in the rate of pulmonary exacerbation (two parallel group randomised } \\
\text { controlled trials and one crossover trial: } \mathrm{RR} 0.25,95 \% \mathrm{Cl} 0.15 \text { to } 0.41 ; \mathrm{P}<0.00001 \text { ) }\end{array}$ \\
\hline $\begin{array}{l}\text { Type } 2 \text { diabetes } \\
\text { (fasting glucose, } \\
\text { glycated } \\
\text { haemoglobin test) }\end{array}$ & Akbari et al $(2016)^{124}$ & $13 / 805$ & Yes & $\begin{array}{l}\text { Probiotics significantly reduced fasting blood glucose compared with placebo ( } 8 \text { studies; } \\
\text { standardised mean difference }-1.583 ; 95 \% \mathrm{Cl}-4.18 \text { to } 4.18 ; \mathrm{P}=0.000 \text { ). Significant reduction } \\
\text { in } \mathrm{HbA}_{1 \mathrm{c}} \text { was also seen ( } 6 \text { studies; } \mathrm{SMD}-1.779 ; 95 \% \mathrm{Cl},-2.657 \text { to }-0.901 ; \mathrm{P}=0.000 \text { ) }\end{array}$ \\
\hline $\begin{array}{l}\text { Type } 2 \text { diabetes } \\
\text { (insulin resistance, } \\
\text { insulin levels) }\end{array}$ & Zhang et al $(2016)^{125}$ & $7 / 425$ & Yes & $\begin{array}{l}\text { Probiotic therapy significantly decreased homeostasis model assessment of insulin resistance } \\
\text { (HOMA-IR) and insulin concentration (WMD: }-1.08,95 \% \mathrm{Cl}-1.88 \text { to }-0.28 \text {; and weighted mean } \\
\text { difference }-1.35 \mathrm{mIU} / \mathrm{L}, 95 \% \mathrm{Cl}--2.38 \text { to }-0.31 \text {, respectively }\end{array}$ \\
\hline $\begin{array}{l}\text { Necrotising } \\
\text { enterocolitis in } \\
\text { pre-term neonates } \\
\text { with focus on } \\
\text { Lactobacillus reuteri }\end{array}$ & Athalye-Jape et al $(2016)^{126}$ & $6 / 1778$ & Yes & $\begin{array}{l}\text { Probiotic reduced duration of hospitalisation (mean difference }=-10.77 \text { days, } 95 \% \mathrm{Cl}-13.67 \\
\text { to }-7.86 \text {; in } 3 \text { randomised controlled trials), and late onset sepsis ( } \mathrm{RR} 0.66 ; 95 \% \mathrm{Cl}, 0.52 \text { to } \\
0.83 ; 4 \mathrm{RCTs} \text { ) were reduced in the }\end{array}$ \\
\hline $\begin{array}{l}\text { Reduction of serum } \\
\text { concentration of } C \\
\text { reactive protein }\end{array}$ & Mazidi et al $(2017)^{127}$ & $19 / 935$ & Yes & $\begin{array}{l}\text { Significant reduction in serum C reactive protein after probiotic administration with a WMD } \\
-1.35 \mathrm{mg} / \mathrm{L},\left(95 \% \mathrm{Cl}-2.15 \text { to }-0.55, \mathrm{I}^{2} 65.1 \%\right)\end{array}$ \\
\hline $\begin{array}{l}\text { Cardiovascular risk } \\
\text { factors in patients } \\
\text { with type } 2 \text { diabetes }\end{array}$ & Hendijani et al $(2017)^{128}$ & $11 / 641$ & Yes & $\begin{array}{l}\text { Probiotic consumption significantly decreased systolic blood pressure ( }-3.28 \mathrm{~mm} \mathrm{Hg} ; 95 \% \mathrm{Cl} \\
-5.38 \text { to }-1.18) \text {, diastolic (WMD }-2.13 \mathrm{~mm} \mathrm{Hg} ; 95 \% \mathrm{Cl}-4.5 \text { to } 0.24) \text {, low density lipoprotein } \\
\text { cholesterol (WMD } 8.32 \mathrm{mg} / \mathrm{dL} ; 95 \% \mathrm{Cl}-15.24 \text { to }-1.4) \text {, total cholesterol }(\mathrm{WMD}-12.19 \mathrm{mg} / \\
\mathrm{dL} ; 95 \% \mathrm{Cl}-17.62 \text { to }-6.75) \text { and triglycerides(WMD }-24.48 \mathrm{mg} / \mathrm{dL} ; 95 \% \mathrm{Cl}-33.77 \text { to }-11.18) \\
\text { compared with placebo }\end{array}$ \\
\hline $\begin{array}{l}\text { Reduction of total } \\
\text { cholesterol and low } \\
\text { density lipoprotein } \\
\text { cholesterol }\end{array}$ & Wu et al $(2017)^{129}$ & $15 / 976$ & Yes & $\begin{array}{l}\text { Lactobacillus consumption significantly reduced total cholesterol by } 0.26 \mathrm{mmol} / \mathrm{L}(95 \% \mathrm{Cl} \\
-0.40 \text { to }-0.12) \text { and LDL-C by } 0.23 \mathrm{mmol} / \mathrm{L}(95 \% \mathrm{Cl},-0.36 \text { to }-0.10)\end{array}$ \\
\hline $\begin{array}{l}\text { Depressive } \\
\text { symptoms }\end{array}$ & Wallace and Milev $(2017)^{79,130}$ & $6 / 1080$ & Yes & $\begin{array}{l}\text { No quantitative analysis was performed. Most studies found positive results, and the authors } \\
\text { conclude that compelling evidence shows that probiotics alleviate depressive symptoms }\end{array}$ \\
\hline $\begin{array}{l}\text { Vulvovaginal } \\
\text { candidiasis in non- } \\
\text { pregnant women }\end{array}$ & Xie et al $(2018)^{131}$ & $10 / 1656$ & Yes & $\begin{array}{l}\text { Probiotics increased the rate of short term clinical cure ( } \mathrm{RR} 1.14,95 \% \mathrm{Cl} 1.05 \text { to } 1.24 \text {, low } \\
\text { quality evidence) and mycological cure ( } \mathrm{RR} 1.06,95 \% \mathrm{Cl} 1.02 \text { to } 1.10 \text {, low quality evidence) and } \\
\text { decreased relapse rate at one month ( } \mathrm{RR} 0.34,95 \% \mathrm{Cl} 0.17 \text { to } 0.68 \text {, low quality evidence) }\end{array}$ \\
\hline
\end{tabular}


profiles of the candidate microbes in inflammation, cancer, lipid metabolism, or obesity. ${ }^{92}$ Stable engraftment of a probiotic Bifidobacterium longum, for example, has been shown to depend on individualised features of the gut microbiota, providing a rationale for the personalisation of probiotic applications. ${ }^{93}$

\section{Personalised nutrition and future directions} Given the variation in the gut microbiota between people, the optimal diet of a person may need to be tailored to their gut microbiota. Zeevi et al..$^{94}$ obtained a multidimensional microbiota profile in 900 people and monitored food intake, continuous blood glucose levels, and physical activity for one week. The researchers devised a machine learning algorithm to predict personalised glucose responses after meals based on clinical and gut microbiome data and showed that it achieved significantly higher predictions than approaches such as carbohydrate counting or glycaemic index scores. In a follow-up double blinded randomised crossover trial of 26 participants, personalised dietary interventions based on the algorithm successfully normalised blood glucose levels. ${ }^{94}$

A study on response to bread ${ }^{68}$ using a randomised crossover trial of one week long dietary interventions showed significant interpersonal variability in the glycaemic response to different bread types. The type of bread that induced the lower glycaemic response in each person could be predicted based solely on microbiome data collected before the intervention. ${ }^{68}$ Much more research is needed to establish whether these kinds of personalised approaches are feasible, sustainable, and have a positive effect on clinical outcomes.

\section{Conclusions}

We are entering an era where we can increasingly modify health through food and measure the effects through our microbes or metabolites. Fibre is a key nutrient for a healthy microbiome and has been overlooked while debates have raged about sugar and fat. The adverse effects on the microbiome of drugs and processed food ingredients can no longer be ignored. Given the current gaps in knowledge, we need clinical evidence that can be translated into clinical practice, ideally through randomised controlled studies that use consistent matrices of prebiotics or probiotics or faecal microbiota transplantation to assess changes in gut microbiota composition and in health outcomes.

Contributors and sources: AMV studies the molecular basis of ageing and complex disease and has recently investigated the role of gut microbiome composition on cardiometabolic disorders. JW has studied and reported widely on the microbial ecology of the gut microbiota, its role in host health, and how it can be modulated by diet. ES heads a multidisciplinary lab of computational biologists and experimental scientists focusing on nutrition, genetics, microbiome, and their effect on health and disease. His aim is to develop personalised nutrition and medicine. TDS leads the TwinsUK registry and British gut project as the head of a multidisciplinary team studying the genetic, dietary, and lifestyle determinants of human gut microbiome composition and its relationship to common diseases. All authors contributed, read, and approved the final version.

Competing interests: We have read and understood BMJ policy on competing interests and declare the following: AMV and TS are consultants to Zoe Global. JW has received research funding from industry sources involved in the manufacture and marketing of prebiotics and dietary fibres and is a co-owner of Synbiotics Solutions, a developer of synbiotic products. ES is a consultant of DayTwo Inc. AMV is funded by the NIHR Nottingham Biomedical Research Centre. JW is supported through the Campus Alberta Innovates programme and grants of the Canadian Institute of Health Research (ClHR), Natural Sciences and Engineering Research Council of Canada (NSERC), the JPI HDHL, and the Canadian Foundation for Innovation. ES is supported by the Crown Human Genome Center; the Else Kroener Fresenius Foundation; Donald L. Schwarz, Sherman Oaks, CA; Jack N Halpern, New York, NY; Leesa Steinberg, Canada; and grants funded by the European Research Council and the Israel Science Foundation. TwinsUK was funded by the Wellcome Trust; European Community's Seventh Framework Programme (FP7/2007-2013). The study also receives support from the National Institute for Health Research (NIHR) BioResource Clinical Research Facility and Biomedica Research Centre based at Guy's and St Thomas' NHS Foundation Trust and King's College London. TDS is an NIHR senior investigator.

Provenance and peer review: Commissioned externally peer reviewed.

This article is one of a series commissioned by The $B M J$. Open access fees for the series were funded by Swiss Re, which had no input on the commissioning or peer review of the articles.

Ana M Valdes, associate professor ${ }^{12}$

Jens Walter, CAIP chair for nutrition, microbes, and gastrointestinal health

Eran Segal, professor ${ }^{4}$

Tim D Spector, professor

${ }^{1}$ School of Medicine, University of Nottingham, City Hospital, Nottingham NG5 1PB, UK

${ }^{2}$ NIHR Nottingham Biomedical Research Centre, Nottingham, UK

${ }^{3}$ Department of Agricultural, Food, and Nutritional Science and Department of Biological Sciences, University of Alberta, Edmonton, Canada

${ }^{4}$ Department of Computer Science and Applied Mathematics, Weizmann Institute of Science, Rehovot, Israel

${ }^{5}$ Department of Twin Research and Genetic Epidemiology, King's College London, London, UK Correspondence to: TDSpector tim.spector@kcl.ac.uk

\section{Bull MJ, Plummer NT. Part 1: The human gut} microbiome in health and disease. Integr Med (Encinitas) 2014;13:17-22.

2 Rath CM, Dorrestein PC. The bacterial chemical repertoire mediates metabolic exchange within gut microbiomes. Curr Opin Microbiol 2012;15:147-54. doi:10.1016/j.mib.2011.12.009

3 Vyas U, Ranganathan N. Probiotics, prebiotics, and synbiotics: gut and beyond. Gastroenterol Res Pract 2012;2012:872716. doi:10.1155/2012/872716

4 Goodrich JK, Waters IL, Poole AC, et al. Human genetics shape the gut microbiome.
Cell 2014;159:789-99. doi:10.1016/j. cell.2014.09.053

Rothschild D, Weissbrod O, Barkan E, et al. Environment dominates over host genetics in shaping human gut microbiota. Nature 2018;555:210-5. doi:10.1038/nature25973

6 Zhang H, Sparks JB, Karyala SV, Settlage R, Luo XM Host adaptive immunity alters gut microbiota. ISME / 2015;9:770-81. doi:10.1038/ismej.2014.165

7 Hakansson A, Molin G. Gut microbiota and inflammation. Nutrients 2011;3:637-82. doi:10.3390/nu3060637

8 Levy M, Kolodziejczyk AA, Thaiss CA, Elinav E. Dysbiosis and the immune system. Nat Rev Immunol 2017:17:219-32. doi:10.1038/nri.2017.7

9 De Palma G, Lynch MD, Lu J, et al. Transplantation of fecal microbiota from patients with irritable bowel syndrome alters gut function and behavior in recipient mice. Sci Transl Med 2017;9:9. doi:10.1126/scitranslmed.aaf6397

10 Wiley NC, Dinan TG, Ross RP, Stanton C, Clarke G, Cryan JF. The microbiota-gut-brain axis as a key regulator of neural function and the stress response: Implications for human and animal health. J Anim Sci 2017:95:3225-46.

11 Sonnenburg ED, Sonnenburg JL. Starving our microbial self: the deleterious consequences of a diet deficient in microbiota-accessible carbohydrates. Cell Metab 2014;20:779-86. doi:10.1016/j. cmet.2014.07.003

12 Beaumont M, Goodrich JK, Jackson MA, et al. Heritable components of the human fecal microbiome are associated with visceral fat. Genome Biol 2016;17:189. doi:10.1186/s13059-0161052-7

13 Falony G, Joossens M, Vieira-Silva S, et al. Populationlevel analysis of gut microbiome variation. Science 2016;352:560-4. doi:10.1126/science.aad3503

14 Vogtmann E, Hua X, Zeller G, et al. Colorectal cancer and the human gut microbiome: Reproducibility with whole-genome shotgun sequencing. PLoS One 2016;11:e0155362. doi:10.1371/journal. pone. 0155362

15 Ranjan R, Rani A, Metwally A, McGee HS, Perkins DL. Analysis of the microbiome: Advantages of whole genome shotgun versus $16 \mathrm{~S}$ amplicon sequencing. Biochem Biophys Res Commun 2016;469:967-77. doi:10.1016/j.bbrc.2015.12.083

16 Zhao L, Ni Y, Su M, et al. High throughput and quantitative measurement of microbial metabolome by gas chromatography/mass spectrometry using automated alkyl chloroformate derivatization. Anal Chem 2017;89:5565-77. doi:10.1021/acs. analchem.7b00660

17 Wong JM, de Souza R, Kendall CW, Emam A, Jenkins DJ. Colonic health: fermentation and short chain fatty acids. J Clin Gastroenterol 2006;40:235-43. doi:10.1097/00004836-200603000-00015

18 De Vadder F, Kovatcheva-Datchary P, Goncalves D, et al. Microbiota-generated metabolites promote metabolic benefits via gut-brain neural circuits. Cell 2014;156:84-96. doi:10.1016/j. cell.2013.12.016

19 Byndloss MX, Olsan EE, Rivera-Chávez F, et al. Microbiota-activated PPAR- $\mu$ signaling inhibits dysbiotic Enterobacteriaceae expansion. Science 2017;357:570-5. doi:10.1126/science. aam9949

20 Frost G, Sleeth ML, Sahuri-Arisoylu M, et al The short-chain fatty acid acetate reduces appetite via a central homeostatic mechanism. Nat Commun 2014;5:3611. doi:10.1038/ ncomms4611

21 Lin HV, Frassetto A, Kowalik EJ Jr, et al. Butyrate and propionate protect against diet-induced obesity and regulate gut hormones via free fatty acid receptor 3-independent mechanisms. PLOS One 2012;7:e35240. doi:10.1371/journal. pone. 0035240

22 Zhao L, Zhang F, Ding X, et al. Gut bacteria selectively promoted by dietary fibers alleviate type 2 diabetes. Science 2018:359:1151-6. doi:10.1126/science. aao 5774 
23 Long SL, Gahan CGM, Joyce SA. Interactions between gut bacteria and bile in health and disease. $\mathrm{Mol}$ Aspects Med 2017;56:54-65. doi:10.1016/ j.mam.2017.06.002

24 Tang WH, Wang Z, Levison BS, et al. Intestinal microbial metabolism of phosphatidylcholine and cardiovascular risk. N Engl J Med 2013;368: 1575-84. doi:10.1056/NEJMoa1109400

25 de Mello VD, Paananen J, Lindström J, et al. Indolepropionic acid and novel lipid metabolites are associated with a lower risk of type 2 diabetes in the Finnish Diabetes Prevention Study. Sci Rep 2017;7:46337. doi:10.1038/srep46337

26 Chyan YJ, Poeggeler B, Omar RA, et al. Potent neuroprotective properties against the Alzheimer beta-amyloid by an endogenous melatoninrelated indole structure, indole-3-propionic acid. J Biol Chem 1999;274:21937-42. doi:10.1074/ jbc.274.31.21937

27 Thaiss CA, Itav S, Rothschild D, et al. Persistent microbiome alterations modulate the rate of postdieting weight regain. Nature 2016. doi:10.1038/ nature20796

28 Menni C, Jackson MA, Pallister T, Steves C), Spector TD, Valdes AM. Gut microbiome diversity and high-fibre intake are related to lower long-term weight gain. Int J Obes (Lond) 2017;41:1099-105. doi:10.1038/ijo.2017.66

29 Gäbele E, Dostert K, Hofmann C, et al. DSS induced colitis increases portal LPS levels and enhances hepatic inflammation and fibrogenesis in experimental NASH.J Hepatol 2011;55:1391-9. doi:10.1016/j.jhep.2011.02.035

30 Baothman OA, Zamzami MA, Taher I, Abubaker J, Abu-Farha M. The role of gut microbiota in the development of obesity and diabetes. Lipids Health Dis 2016;15:108. doi:10.1186/s12944-0160278-4

31 Manichanh C, Rigottier-Gois L, Bonnaud E, et al. Reduced diversity of faecal microbiota in Crohn's disease revealed by a metagenomic approach. Gut 2006;55:205-11. doi:10.1136/ gut.2005.073817

32 Scher JU, Ubeda C, Artacho A, et al. Decreased bacterial diversity characterizes the altered gut microbiota in patients with psoriatic arthritis, resembling dysbiosis in inflammatory bowel disease. Arthritis Rheumatol 2015;67:128-39. doi:10.1002/ art.38892

33 de Goffau MC, Luopajärvi K, Knip M, et al. Fecal microbiota composition differs between children with $\beta$-cell autoimmunity and those without. Diabetes 2013;62:1238-44. doi:10.2337/ db12-0526

34 Wang M, Karlsson C, Olsson C, et al. Reduced diversity in the early fecal microbiota of infants with atopic eczema. J Allergy Clin Immunol 2008;121:129-34. doi:10.1016/ j.jaci.2007.09.011

35 Schippa S, lebba V, Barbato M, et al. A distinctive 'microbial signature' in celiac pediatric patients. BMC Microbiol 2010;10:175. doi:10.1186/1471-218010-175

36 Turnbaugh PJ, Hamady M, Yatsunenko T, et al. A core gut microbiome in obese and lean twins. Nature 2009;457:480-4. doi:10.1038/ nature 07540

37 Lambeth SM, Carson T, Lowe J, et al. Composition, diversity and abundance of gut microbiome in prediabetes and type 2 diabetes. I Diabetes Obes 2015;2:1-7

38 Menni C, Lin C, Cecelja M, et al. Gut microbial diversity is associated with lower arterial stiffness in women. Eur Heart I 2018.•••.39.

39 Opstelten JL, Plassais J, van Mil SW, et al. Gut microbial diversity is reduced in smokers with Crohn's disease. Inflamm Bowel Dis 2016;22:2070-7. doi:10.1097/ MIB.0000000000000875

40 Sommer F, Rühlemann MC, Bang C, et al. Microbiomarkers in inflammatory bowel diseases: caveats come with caviar. Gut 2017;66:1734-8 doi:10.1136/gutjnl-2016-313678

41 Sommer F, Anderson JM, Bharti R, Raes J, Rosenstiel P. The resilience of the intestinal microbiota influences health and disease. Nat Rev Microbiol 2017;15: 630-8. doi:10.1038/nrmicro.2017.58

42 DeFilipp Z, Peled JU, Li S, et al. Third-party fecal microbiota transplantation following allo-HCT reconstitutes microbiome diversity. Blood Adv 2018;2:745-53. doi:10.1182/ bloodadvances.2018017731

43 Schneider KM, Wirtz TH, Kroy D, et al. Successful fecal microbiota transplantation in a patient with severe complicated Clostridium difficile infection after liver transplantation. Case Rep Gastroenterol 2018;12:76-84 doi:10.1159/000481937

44 Cammarota G, laniro G, Tilg H, et al, European FMT Working Group. European consensus conference on faecal microbiota transplantation in clinical practice. Gut 2017;66:569-80. doi:10.1136/ gutjnl-2016-313017

45 Kootte RS, Levin E, Salojarvi I, et al. Improvement of insulin sensitivity after lean donor feces in metabolic syndrome is driven by baseline intestinal microbiota composition. Cell metabolism. 2017; 26: 611-9 e6.

46 Nettleton JE, Reimer RA, Shearer J. Reshaping the gut microbiota: Impact of low calorie sweeteners and the link to insulin resistance? Physiol Behav 2016;164(Pt B):488-93. doi:10.1016/j.physbeh.2016.04.029

47 Abou-Donia MB, El-Masry EM, Abdel-Rahman AA, McLendon RE, Schiffman SS. Splenda alters gut microflora and increases intestinal p-glycoprotein and cytochrome p-450 in male rats. J Toxicol Environ Health A 2008;71:1415-29. doi:10.1080/15287390802328630

48 Bian X, Chi L, Gao B, Tu P, Ru H, Lu K. Gut microbiome response to sucralose and its potential role in inducing liver inflammation in mice. Front Physiol 2017;8:487. doi:10.3389/ fphys.2017.00487

49 Chassaing B, Koren O, Goodrich JK, et al. Dietary emulsifiers impact the mouse gut microbiota promoting colitis and metabolic syndrome. Nature 2015;519:92-6. doi:10.1038/nature14232

50 Wu GD, Compher C, Chen EZ, et al. Comparative metabolomics in vegans and omnivores reveal constraints on diet-dependent gut microbiota metabolite production. Gut 2016;65:63-72. doi:10.1136/gutjnl-2014-308209

51 Mohan M, Chow CT, Ryan CN, et al. Dietary gluten-induced gut dysbiosis is accompanied by selective upregulation of microRNAs with intestinal tight junction and bacteria-binding motifs in rhesus macaque model of celiac disease. Nutrients 2016;8:8. doi:10.3390/nu8110684

52 Bevilacqua A, Costabile A, Bergillos-Meca T, et al. Impact of gluten-friendly bread on the metabolism and function of in vitro gut microbiota in healthy human and coeliac subjects. PLoS One 2016;11:e0162770. doi:10.1371/journal. pone. 0162770

53 Lebwohl B, Cao Y, Zong G, et al. Long term gluten consumption in adults without celiac disease and risk of coronary heart disease: prospective cohort study. BMJ 2017;357:j1892. doi:10.1136/bmj.j1892

54 Bonder M), Tigchelaar EF, Cai X, et al. The influence of a short-term gluten-free diet on the human gut microbiome. Genome Med 2016;8:45. doi:10.1186/ s13073-016-0295-y

55 Halmos EP. When the low FODMAP diet does not work. J Gastroenterol Hepatol 2017;32(Suppl 1): 69-72. doi:10.1111/jgh.13701

56 Gibson PR. The evidence base for efficacy of the low FODMAP diet in irritable bowel syndrome: is it ready for prime time as a first-line therapy? J Gastroenterol Hepatol 2017;32(Suppl 1):32-5. doi:10.1111/ jgh.13693

57 Bennet SMP, Bohn L, Storsrud S, et al. Multivariate modelling of faecal bacterial profiles of patients with IBS predicts responsiveness to a diet low in FODMAPs. Gut 2017

58 McIntosh K, Reed DE, Schneider T, et al. FODMAPs alter symptoms and the metabolome of patients with IBS: a randomised controlled trial. Gut 2017;66:1241-51. doi:10.1136/ gutjnl-2015-311339

59 Staudacher HM, Whelan K. The low FODMAP diet recent advances in understanding its mechanisms and efficacy in IBS. Gut 2017;66:1517-27. doi:10.1136/gutinl-2017-313750

60 Jackson MA, Goodrich JK, Maxan ME, et al. Proton pump inhibitors alter the composition of the gut microbiota. Gut 2016;65:749-56. doi:10.1136/ gutjnl-2015-310861

61 Blaser MJ. Antibiotic use and its consequences for the normal microbiome. Science 2016;352:544-5. doi:10.1126/science.aad9358

62 Reijnders D, Goossens GH, Hermes GD, et al. Effects of gut microbiota manipulation by antibiotics on host metabolism in obese humans: A randomized double-blind placebo-controlled trial. Cell Metab 2016;24:63-74. doi:10.1016/j. cmet.2016.06.016

63 Lee YM, Kim KS, Jacobs DR Jr, Lee DH. Persistent organic pollutants in adipose tissue should be considered in obesity research. Obes Rev 2017;18:129-39. doi:10.1111/obr.12481

64 Alexander JL, Wilson ID, Teare J, Marchesi JR, Nicholson JK, Kinross JM. Gut microbiota modulation of chemotherapy efficacy and toxicity. Nat Rev Gastroenterol Hepatol 2017;14:356-65. doi:10.1038/nrgastro.2017.20

65 Spanogiannopoulos P, Bess EN, Carmody RN, Turnbaugh PJ. The microbial pharmacists within us: a metagenomic view of xenobiotic metabolism. Nat Rev Microbiol 2016:14:273-87. doi:10.1038/ nrmicro.2016.17

66 O'Keefe SJ, Li JV and Lahti L. Fat, fibre and cancer risk in African Americans and rural Africans. 2015; 6 : 6342

67 David LA, Maurice CF, Carmody RN, et al. Diet rapidly and reproducibly alters the human gut microbiome. Nature 2014;505:559-63. doi:10.1038/ nature 12820

68 Korem T, Zeevi D, Zmora N, et al. Bread affects clinical parameters and induces gut microbiome-associated personal glycemic responses. Cell Metabolism. 2017 25: $1243-53$ e5.

69 Jones JM. CODEX-aligned dietary fiber definitions help to bridge the 'fiber gap'. Nutr J 2014;13:34 doi:10.1186/1475-2891-13-34

70 Deehan EC, Duar RM, Armet AM, Perez-Muñoz ME, Jin M, Walter J. Modulation of the gastrointestinal microbiome with nondigestible fermentable carbohydrates to Improve human health. Microbio Spectr 2017;5:5. doi:10.1128/microbiolspec.BAD0019-2017

71 Bindels LB, Delzenne NM, Cani PD, Walter J. Towards a more comprehensive concept for prebiotics. Nat Rev Gastroenterol Hepatol 2015;12:303-10. doi:10.1038/nrgastro.2015.47

72 Olle B. Medicines from microbiota. Nat Biotechnol 2013;31:309-15. doi:10.1038/ nbt. 2548

73 Walter J. Murine gut microbiota-diet trumps genes. Cell Host Microbe 2015;17:3-5. doi:10.1016/j. chom.2014.12.004

74 Venkataraman A, Sieber IR, Schmidt AW, Waldron C, Theis KR, Schmidt TM. Variable responses of human microbiomes to dietary supplementation with resistant starch. Microbiome 2016;4:33. doi:10.1186/s40168-016-0178-x

75 Martínez I, Kim J, Duffy PR, Schlegel VL, Walter J. Resistant starches types 2 and 4 have differential effects on the composition of the fecal microbiota in human subjects. PLoS One 2010;5:e15046. doi:10.1371/journal.pone.0015046

76 Koropatkin NM, Cameron EA, Martens EC. How glycan metabolism shapes the human gut microbiota. Nat Rev Microbiol 2012;10:323-35. doi:10.1038/ nrmicro2746

77 Walker AW, Ince J, Duncan SH, et al. Dominant and diet-responsive groups of bacteria within the human colonic microbiota. ISME J 2011;5:220-30. doi:10.1038/ismej.2010.118

78 Cummings JH, Macfarlane GT. The control and consequences of bacterial fermentation in the human colon. / Appl Bacteriol 1991:70:443-59. doi:10.1111/j.1365-2672.1991.tb02739.x

79 Russell WR, Gratz SW, Duncan SH, et al. High-protein, reduced-carbohydrate weight-loss diets promote metabolite profiles likely to be detrimental to 
colonic health. Am J Clin Nutr 2011;93:1062-72. doi:10.3945/ajcn.110.002188

80 Duncan SH, Belenguer A, Holtrop G, Johnstone AM, Flint HJ, Lobley GE. Reduced dietary intake of carbohydrates by obese subjects results in decreased concentrations of butyrate and butyrate-producing bacteria in feces. Appl Environ Microbiol 2007;73:1073-8. doi:10.1128/ AEM.02340-06

81 Desai MS, Seekatz AM, Koropatkin NM, et al. A dietary fiber-deprived gut microbiota degrades the colonic mucus barrier and enhances pathogen susceptibility. Cell 2016;167:1339-1353.e21. doi:10.1016/j.cell.2016.10.043

82 Earle KA, Billings G, Sigal M, et al. Quantitative imaging of gut microbiota spatial organization. Cell Host Microbe 2015;18:478-88. doi:10.1016/j. chom.2015.09.002

83 Zou J, Chassaing B, Singh V, et al. Fiber-mediated nourishment of gut microbiota protects against diet-induced obesity by restoring IL-22-mediated colonic health. Cell Host Microbe 2018;23:41-53.e4. doi:10.1016/j.chom.2017.11.003

84 Schroeder BO, Birchenough GMH, StåhIman M, et al. Bifidobacteria or fiber protects against diet-induced microbiota-mediated colonic mucus deterioration. Cell Host Microbe 2018;23:27-40.e7. doi:10.1016/j. chom.2017.11.004

85 Ray K. Gut microbiota: Filling up on fibre for a healthy gut. Nat Rev Gastroenterol Hepatol 2018;15:67. doi:10.1038/nrgastro.2018.2

86 Veronese N, Solmi M, Caruso MG, et al. Dietary fiber and health outcomes: an umbrella review of systematic reviews and meta-analyses. Am J Clin Nutr 2018;107:436-44. doi:10.1093/ajcn/ nqx082

87 Thompson SV, Hannon BA, An R, Holscher HD. Effects of isolated soluble fiber supplementation on body weight, glycemia, and insulinemia in adults with overweight and obesity: a systematic review and meta-analysis of randomized controlled trials. Am J Clin Nutr 2017;106:1514-28. doi:10.3945/ ajcn.117.163246

88 Hill C, Guarner F, Reid G, et al. Expert consensus document. The International Scientific Association for Probiotics and Prebiotics consensus statement on the scope and appropriate use of the term probiotic. Nat Rev Gastroenterol Hepatol 2014;11:506-14. doi:10.1038/nrgastro.2014.66

89 Kristensen NB, Bryrup T, Allin KH, Nielsen T, Hansen TH, Pedersen O. Alterations in fecal microbiota composition by probiotic supplementation in healthy adults: a systematic review of randomized controlled trials. Genome Med 2016;8:52. doi:10.1186/s13073-016 0300-5

90 Walter J, Maldonado-Gómez MX, Martínez I. To engraft or not to engraft: an ecological framework for gut microbiome modulation with live microbes. Curr Opin Biotechnol 2018;49:129-39. doi:10.1016/j. copbio.2017.08.008

91 Plovier H, Everard A, Druart C, et al. A purified membrane protein from Akkermansia muciniphila or the pasteurized bacterium improves metabolism in obese and diabetic mice. Nat Med 2017;23:107-13. doi: $10.1038 / n m .4236$

92 Chua KJ, Kwok WC, Aggarwal N, Sun T, Chang MW. Designer probiotics for the prevention and treatment of human diseases. Curr Opin Chem Biol 2017;40: 8-16. doi:10.1016/j.cbpa.2017.04.011

93 Maldonado-Gómez MX, Martínez I, Bottacini F, et al. Stable engraftment of Bifidobacterium longum AH1206 in the human gut depends on individualized features of the resident microbiome. Cell Host Microbe 2016;20:515-26. doi:10.1016/ j.chom.2016.09.001

94 Zeevi D, Korem T, Zmora N, et al. Personalized nutrition by prediction of glycemic responses. Cell 2015;163:1079-94. doi:10.1016/j. cell.2015.11.001

95 Deehan EC, Walter J. The fiber gap and the disappearing gut microbiome: Implications for human nutrition. Trends Endocrinol Metab 2016;27:239-42. doi:10.1016/j. tem.2016.03.001
96 Hakim H, Dallas R, Wolf J, et al. Gut microbiome composition predicts infection risk during chemotherapy in children with acute lymphoblastic leukemia. Clin Infect Dis 2018. doi:10.1093/cid/ ciy153.

97 Uchida M, Mogami O, Matsueda K. Characteristic of milk whey culture with Propionibacterium freudenreichii ET-3 and its application to the inflammatory bowel disease therapy. Inflammopharmacology 2007;15:105-8. doi:10.1007/s10787-007-1557-5

98 Foligné B, Breton J, Mater D, Jan G. Tracking the microbiome functionality: focus on Propionibacterium species. Gut 2013;62:1227-8. doi:10.1136/gutjnl-2012-304393

99 Zheng H, Yde CC, Clausen MR, et al. Metabolomics investigation to shed light on cheese as a possible piece in the French paradox puzzle. I Agric Food Chem 2015;63:2830-9. doi:10.1021/ jf505878a

100 Montel MC, Buchin S, Mallet A, et al. Traditional cheeses: rich and diverse microbiota with associated benefits. Int I Food Microbiol 2014:177:136-54. doi:10.1016/j.ijfoodmicro.2014.02.019

101 Sasaki D, Sasaki K, Ikuta N, et al. Low amounts of dietary fibre increase in vitro production of short-chain fatty acids without changing human colonic microbiota structure. Sci Rep 2018;8:435 doi:10.1038/s41598-017-18877-8

102 Cheng W, Lu J, Li B, et al. Effect of functional oligosaccharides and ordinary dietary fiber on intestinal microbiota diversity. Front Microbiol 2017:8:1750 doi:10.3389/ fmicb.2017.01750

103 Administration FaD. Code of Federal Regulations Title 21 Subpart E: Specific Requirements for Health Claims[23 pp.]. EFSA / 2016;14:4369.

104 Rodriguez-Palacios A, Harding A, Menghini P, et al. The artificial sweetener Splenda promotes gut Proteobacteria, dysbiosis, and myeloperoxidase reactivity in Crohn's disease-like ileitis. Inflamm Bowel Dis 2018;24:1005-20. doi:10.1093/ibd/ izy060

105 Suez J, Korem T, Zeevi D, et al. Artificial sweeteners induce glucose intolerance by altering the gut microbiota. Nature 2014;514:181-6. doi:10.1038/ nature13793

106 Moreno-Indias I, Sánchez-Alcoholado L, Pérez-Martínez P, et al. Red wine polyphenols modulate fecal microbiota and reduce markers of the metabolic syndrome in obese patients. Food Funct 2016;7:1775-87. doi:10.1039/ C5F000886G

107 Etxeberria U, Arias N, Boqué N, et al. Reshaping faecal gut microbiota composition by the intake of trans-resveratrol and quercetin in high-fat sucrose diet-fed rats. / Nutr Biochem 2015;26:651-60. doi:10.1016/j.jnutbio.2015.01.002

108 Ozdal T, Sela DA, Xiao J, Boyacioglu D, Chen F, Capanoglu E. The reciprocal interactions between polyphenols and gut microbiota and rffects on bioaccessibility. Nutrients 2016;8:78. doi:10.3390/ nu8020078

109 Orlich MJ, Singh PN, Sabaté J, et al. Vegetarian dietary patterns and mortality in Adventist Health Study 2. IAMA Intern Med 2013;173:1230-8. doi:10.1001/ jamainternmed.2013.6473

110 Mihrshahi S, Ding D, Gale J, Allman-Farinelli M, Banks E, Bauman AE. Vegetarian diet and all-cause mortality: Evidence from a large population-based Australian cohort - the 45 and Up Study. Prev Med 2017;97:1-7. doi:10.1016/j. ypmed.2016.12.044

111 Goldenberg JZ, Yap C, Lytvyn L, et al. Probiotics for the prevention of Clostridium difficile-associated diarrhea in adults and children. Cochrane Database Syst Rev 2017;12:CD006095.

112 AlFaleh K, Anabrees J. Probiotics for prevention of necrotizing enterocolitis in preterm infants. Cochrane Database Syst Rev 2014:(4):CD005496.

113 Rees CM, Hall NJ, Fleming P, Eaton S. Probiotics for the prevention of surgical necrotising enterocolitis: systematic review and meta-analysis. $B M$ J Paediatr Open 2017:1:e000066. doi:10.1136/ bmjpo-2017-000066
114 Goldenberg JZ, Lytvyn L, Steurich J, Parkin P, Mahant S, Johnston BC. Probiotics for the prevention of pediatric antibioticassociated diarrhea. Cochrane Database Syst Rev 2015:(12):CD004827.

115 Hao Q, Dong BR, Wu T. Probiotics for preventing acute upper respiratory tract infections. Cochrane Database Syst Rev 2015;(2):CD006895.

116 Schwenger EM, Tejani AM, Loewen PS. Probiotics for preventing urinary tract infections in adults and children. Cochrane Database Syst Rev 2015;(12):CD008772

117 Azad MB, Coneys JG, Kozyrskyj AL, et al. Probiotic supplementation during pregnancy or infancy for the prevention of asthma and wheeze: systematic review and meta-analysis. BMJ 2013;347:f6471 doi:10.1136/bmj.f6471

118 Mansfield JA, Bergin SW, Cooper JR, Olsen CH. Comparative probiotic strain efficacy in the prevention of eczema in infants and children: a systematic review and meta-analysis. Mil Med 2014;179:580-92. doi:10.7205/ MILMED-D-13-00546

119 Agrawal S, Rao S, Patole S. Probiotic supplementation for preventing invasive fungal infections in preterm neonates--a systematic review and meta-analysis. Mycoses 2015:58:642-51. doi:10.1111/ myc. 12368

120 Manzanares W, Lemieux M, Langlois PL, Wischmeyer PE. Probiotic and synbiotic therapy in critical illness: a systematic review and metaanalysis. Crit Care 2016;19:262. doi:10.1186/ s13054-016-1434-y

121 Ahmadi E, Alizadeh-Navaei R, Rezai MS. Efficacy of probiotic use in acute rotavirus diarrhea in children A systematic review and meta-analysis. Caspian Intern Med 2015;6:187-95.

122 Saez-Lara MJ, Gomez-Llorente C, Plaza-Diaz J, Gil A. The role of probiotic lactic acid bacteria and bifidobacteria in the prevention and treatment of inflammatory bowel disease and other related diseases: a systematic review of randomized human clinical trials. Biomed Res Int 2015;2015:505878. doi:10.1155/2015/505878

123 Ananthan A, Balasubramanian H, Rao S, Patole S. Probiotic supplementation in children with cystic fibrosis-a systematic review. Eur J Pediatr 2016;175:1255-66. doi:10.1007/s00431016-2769-8

124 Akbari V, Hendijani F. Effects of probiotic supplementation in patients with type 2 diabetes: systematic review and meta-analysis. Nutr Rev 2016;74:774-84. doi:10.1093/nutrit/ nuw039

125 Zhang Q. Wu Y, Fei X. Effect of probiotics on glucose metabolism in patients with type 2 diabetes mellitus: A meta-analysis of randomized controlled trials. Medicina (Kaunas) 2016;52:28-34. doi:10.1016/j. medici.2015.11.008

126 Athalye-Jape G, Rao S, Patole S. Lactobacillus reuteri DSM 17938 as a probiotic for preterm neonates: A strain-specific systematic review. JPEN J Parenter Enteral Nutr 2016;40:783-94. doi:10.1177/0148607115588113

127 Mazidi M, Rezaie P, Ferns GA, Vatanparast H. Impact of probiotic administration on serum C-reactive protein concentrations: Systematic review and meta-Aanalysis of randomized control trials. Nutrients 2017;9:9. doi:10.3390/ nu9010020

128 Hendijani F, Akbari V. Probiotic supplementation for management of cardiovascular risk factors in adults with type II diabetes: A systematic review and metaanalysis. Clin Nutr 2017

129 Wu Y, Zhang Q, Ren Y, Ruan Z. Effect of probiotic Lactobacillus on lipid profile: A systematic review an meta-analysis of randomized, controlled trials. PLOS One 2017;12:e0178868. doi:10.1371/journal. pone. 0178868

130 Wallace CJK, Milev R. The effects of probiotics on depressive symptoms in humans: a systematic review. Ann Gen Psychiatry 2017;16:14. doi:10.1186/s12991-017-0138-2 
131 Xie HY, Feng D, Wei DM, et al. Probiotics for vulvovaginal candidiasis in non-pregnant women. Cochrane Database Syst Rev 2017;11:CD010496. 132 Ikram S, Hassan N, Raffat MA, Mirza S, Akram Z. Systematic review and meta-analysis of double-blind, placebo-controlled, randomized clinical trials using probiotics in chronic periodontitis. / Investig Clin Dent 2018;•••:e12338. doi:10.1111/jicd.12338 104 So D, Whelan K, Rossi M, et al. Dietary fiber intervention on gut microbiota composition in healthy adults: a systematic review and metaanalysis. Am J Clin Nutr 2018;•••. doi:10.1093/ajcn/ nqy0 41

Cite this as: $B M / 2018 ; 361: j 2179$

http://dx.doi.org/10.1136/bmj.j2179

This an open access article distributed under the terms of the Creative Commons Attribution-non-commercial IGO License (https:// creativecommons.org/licenses/by-nc/3.0/igo/), which permits use, distribution, and reproduction for non-commercial purposes in any medium, provided the original work is properly cited. In any reproduction of this article there should not be any suggestion that WHO or this article endorse any specific organisation or products. The use of the WHO logo is not permitted. This notice should be preserved along with the article's original URL 